Article

\title{
One New and Nine Known Flavonoids from Choerospondias axillaries and Their in Vitro Antitumor, Anti-Hypoxia and Antibacterial Activities
}

\section{Chang-Wei Li and Cheng-Bin Cui *}

State Key Laboratory of Toxicology and Medical Countermeasures, Beijing Institute of Pharmacology and Toxicology, Beijing 100850, China; E-Mail: sdrlcw@126.com

* Author to whom correspondence should be addressed; E-Mail: cuicb@126.com;

Tel./Fax: +86-10-6821-1656.

External Editor: Derek J. McPhee

Received: 23 October 2014; in revised form: 8 December 2014 / Accepted: 12 December 2014 / Published: 19 December 2014

\begin{abstract}
In the present study, a new flavanoid 1, together with nine known ones 2-10 were isolated from the stem bark of Choerospondias axillaries, the fruit of which was used mainly for treatment of cardiovascular diseases in China. The structure of $\mathbf{1}$ was established on the basis of its extensive spectral data, and the absolute structures of $\mathbf{1}$ and 10 were determined by their CD data. The absolute structure of $\mathbf{1 0}$ was established for the first time. Among the obtained compounds, 5-8 inhibited the proliferation of K562 cells with inhibition rates of $26.6 \%, 65.7 \%, 40.4 \%$ and $45.6 \%$ at $100 \mu \mathrm{g} / \mathrm{mL} ; \mathbf{1}$ and $\mathbf{4 - 1 0}$ showed significant protective effects on anoxia-induced injury in cultured ECV304 or PC12 cells at $50 \mu \mathrm{g} / \mathrm{mL} ; \mathbf{8}$ and $\mathbf{9}$ showed antibacterial effects on Staphylococcus aureus ATCC6538 at the tested concentration of $150 \mu \mathrm{g} / 8 \mathrm{~mm}$ paper disc. Compounds $\mathbf{2}$ and 4-10 were isolated for the first time from this genus. The proliferation inhibiting activities of 7 and $\mathbf{8}$, the anti-hypoxia activities of $\mathbf{1}$ and 4-10, and the antibacterial effect of $\mathbf{8}$ and $\mathbf{9}$ on Staphylococcus aureus ATCC6538 are reported here for the first time.
\end{abstract}

Keywords: Choerospondias axillaries; isolation; flavonoids; antitumor; anti-hypoxia; antibacterial 


\section{Introduction}

Choerospondias axillaries, the only plant of the genus Choerospondias belonging to the family of Anacardiaceae, is mainly distributed in the Hubei, Guangdong, Guangxi, Yunnan, Fujian and Guizhou provinces of China. In China, the dried fruit of $C$. axillaries has been usually used for the treatment of cardiovascular diseases, especially in Mongolian traditional medicine [1,2]. Chemical studies of the plant have revealed the presence of phenolic compounds, flavonoids, sterols, organic acids and polysaccharides, and the total flavonoids were always assumed to be the effective constituents behind its medicinal usage [2]. Our previous work on screening herbal medicines for antitumor activity showed that the ethanol extract of the stem bark of $C$. axillaries exhibited strong cytotoxicity [3,4]. An ongoing study of its bioactive constituents has now led to isolation of one new and nine known flavonoids 1-10 (Figure 1). In this work, the isolation, identification, the absolute structure determination and bioactivities of the ten flavonoids $\mathbf{1}-\mathbf{1 0}$ are reported.

Figure 1. Structures of compounds 1-10.<smiles>[R]c1cc(O)c2c(c1)O[C@H](c1ccc([R4])c([R3])c1)[C@H]([R2])C(=O)C2[R4]</smiles>

2: $\mathrm{R}_{1}=$ OGlc, $\mathrm{R}_{2}=\mathrm{R}_{3}=\mathrm{R}_{4}=\mathrm{H}$

3: $\mathrm{R}_{1}=\mathrm{OH}, \mathrm{R}_{2}=\mathrm{R}_{3}=\mathrm{H}, \mathrm{R}_{4}=\mathrm{OGlc}$

4: $\mathrm{R}_{1}=\mathrm{OGlc}, \mathrm{R}_{2}=\mathrm{R}_{4}=\mathrm{OH}, \mathrm{R}_{3}=\mathrm{H}$

5: $\mathrm{R}_{1}=\mathrm{OGlc}, \mathrm{R}_{2}=\mathrm{R}_{4}=\mathrm{R}_{3}=\mathrm{OH}$<smiles>O=c1c(O)c(-c2ccc(O)c(O)c2)oc2cc(O[C@@H]3O[C@H](CO)[C@@H](O)[C@H](O)[C@H]3O)cc(O)c12</smiles>

6<smiles>Oc1cccc([C@H]2Oc3c(c(O)cc(O)c3-c3cc(O)c(O)cc3[C@H]3Oc4cc(O)cc(O)c4[C@@H](O)C[C@H]3O)C[C@H]2O)c1</smiles>

9<smiles>Oc1cc(O)c(C[13CH2][C@@H](c2c(O)cc3c(c2O)C[C@H](O)[C@@H](c2ccc(O)c(O)c2)O3)[C@H](O)c2ccc(O)c(O)c2)c(O)c1</smiles>

7

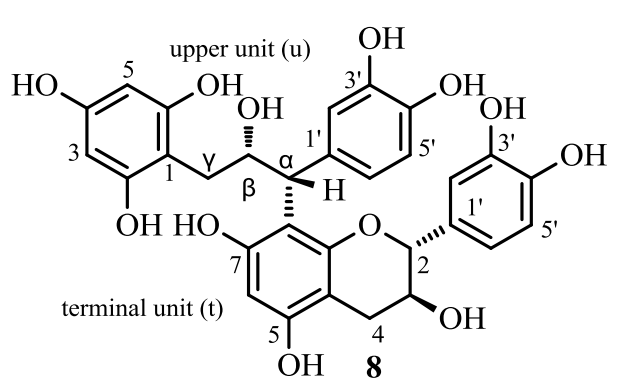<smiles>O=C1C=C2c3c(cc(O)c4c3O[C@@H]1[C@@H](O)C(O)C4)OC21CC(O)[C@H](c2ccc(O)c(O)c2)O1</smiles>

10 


\section{Results and Discussion}

\subsection{Structure Elucidation of $\mathbf{1}$ and Identification of $\mathbf{2}-\mathbf{1 0}$}

Compound 1 was obtained as white needle-like crystals, m.p. $160-162{ }^{\circ} \mathrm{C}$ (from $30 \%$ methanol/water solution), $[\alpha]_{\mathrm{D}}^{25}-18.9^{\circ}$ (c $1.0, \mathrm{MeOH}$ ), and showed a dark blue coloration upon spraying with $\mathrm{FeCl}_{3}$ reagent on the silica gel TLC plate. Positive ion HR-ESI-MS showed a quasi-molecular ion peak at $\mathrm{m} / \mathrm{z}$ $587.14907[\mathrm{M}+\mathrm{H}]^{+}$, and adduct peaks at $609.12290[\mathrm{M}+\mathrm{Na}]^{+}$and $625.09327[\mathrm{M}+\mathrm{K}]^{+}$corresponding to a formula of $\mathrm{C}_{28} \mathrm{H}_{26} \mathrm{O}_{14}$. Its UV spectrum showed a maximum absorption at $286 \mathrm{~nm}(\log \varepsilon, 4.03)$ arising from the hydroxylated phenyl groups. Its IR spectrum displayed characteristic absorptions for hydroxyl $\left(3293 \mathrm{~cm}^{-1}\right)$ and carbonyls $\left(1685\right.$ and $\left.1637 \mathrm{~cm}^{-1}\right)$. The ${ }^{1} \mathrm{H}-\mathrm{NMR}$ spectrum showed aliphatic proton signals at $\delta 3.07(1 \mathrm{H}, \mathrm{dd}, J=16.8,12.8 \mathrm{~Hz})$ and at $\delta 2.66(1 \mathrm{H}, \mathrm{dd}, J=16.8,2.8 \mathrm{~Hz})$ from the axial and equatorial methylene protons at $\mathrm{C}-3$ as well as a third aliphatic resonance at $\delta 5.31(1 \mathrm{H}$, dd, $J=12.8,2.8 \mathrm{~Hz}$ ) from the methine proton, which bears an oxygen and phenyl function at $\mathrm{C}-2$ of the flavanone moiety. The AA'BB' system at $\delta 7.29(2 \mathrm{H}, \mathrm{d}, J=8.4 \mathrm{~Hz})$ and at $\delta 7.06(2 \mathrm{H}, \mathrm{d}, J=8.4 \mathrm{~Hz})$, and an AX system at $\delta 5.90(1 \mathrm{H}, \mathrm{d}, J=2.0 \mathrm{~Hz})$ and at $\delta 5.88(1 \mathrm{H}, \mathrm{d}, J=2.0 \mathrm{~Hz})$ were in accordance with derivatives of 5,7,4'-trihydroxyflavonone, i.e., derivatives of naringenin. The anomeric proton signal at $\delta 4.91(1 \mathrm{H}, \mathrm{d}, J=7.6 \mathrm{~Hz})$ revealed the presence of one sugar with a $\beta$ configuration. The ${ }^{13} \mathrm{C}-\mathrm{NMR}$ signals at $\delta 101.5,77.5,75.1,74.3,71.5$ and 64.4 indicated that the sugar should be glucosyl group [5], so except for the additional signals [ $\delta \mathrm{C}: 167.9,146.0$ (2C), 139.4, 120.8, 109.8 (2C)] arising from a galloyl group, the ${ }^{13} \mathrm{C}-\mathrm{NMR}$ data of 1 were closely similar to those of naringenin-4'-O- $\beta$-Dglucopyranoside (3) (Table 1). The linkage of the glucopyranosyl moiety to the 4'-hydroxyl group of naringenin was confirmed by the HMBC correlation between the anomeric proton at $\delta 4.91(1 \mathrm{H}, \mathrm{d}$, $J=7.6 \mathrm{~Hz}$ ) of the glucopyranosyl moiety and C-4' at $\delta 158.5$ (Figure 2). The location of the galloyl was determined to be the glucose C- 6 " position according to the HMBC correlations between the glucose $6 "$-H and carbonyl carbon of galloyl group (Figure 2), which was also supported by the downfield shift of glucose $6^{\prime \prime}-\mathrm{H}$ at $\delta 4.38(1 \mathrm{H}, \mathrm{dd}, J=8.4,12.0 \mathrm{~Hz})$ and $4.61(1 \mathrm{H}, \mathrm{dd}, J=2.0,12.0 \mathrm{~Hz})$. Thus, compound 1 was identified as narigenin-4'-O-(6"-O-galloyl- $\beta$-D-glucopyranoside).

Figure 2. Structure and the HMBC correlations of 1.

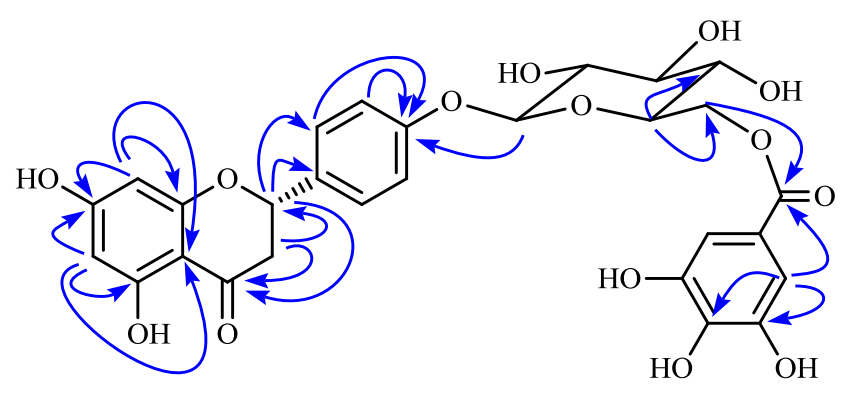

HMBC correlations 
Table 1. $400 \mathrm{MHz}{ }^{1} \mathrm{H}-\mathrm{NMR}$ and $100 \mathrm{MHz}{ }^{13} \mathrm{C}-\mathrm{NMR}$ data of $\mathbf{1}$ and $\mathbf{3}^{\mathrm{a}}$.

\begin{tabular}{|c|c|c|c|c|}
\hline \multirow{2}{*}{ Position } & \multicolumn{2}{|l|}{$1\left(\right.$ in $\left.\mathrm{CD}_{3} \mathrm{OD}\right)$} & \multicolumn{2}{|l|}{3 ( in DMSO- $d_{6}$ ) } \\
\hline & $\delta_{\mathrm{H}}$ & $\delta_{\mathrm{C}}$ & $\delta_{\mathrm{H}}$ & $\delta_{\mathrm{C}}$ \\
\hline \multicolumn{5}{|l|}{ narigenin } \\
\hline 2 & $5.31(1 \mathrm{H}, \mathrm{dd}, J=12.8,2.8 \mathrm{~Hz})$ & 79.7 & $5.53(1 \mathrm{H}, \mathrm{dd}, J=12.4,3.0 \mathrm{~Hz})$ & 78.6 \\
\hline 3 & $\begin{array}{l}3.07(1 \mathrm{H}, \mathrm{dd}, J=16.8,12.8 \mathrm{~Hz}) \\
2.66(1 \mathrm{H}, \mathrm{dd}, J=16.8,2.8 \mathrm{~Hz})\end{array}$ & 43.3 & $\begin{array}{l}\text { Overlapped } \\
2.74(1 \mathrm{H}, \mathrm{dd}, J=17.2,3.0 \mathrm{~Hz})\end{array}$ & 42.5 \\
\hline 4 & & 197.3 & & 196.7 \\
\hline $4 a$ & & 102.9 & & 102.3 \\
\hline 5 & & 164.9 & & 163.3 \\
\hline 6 & $5.90(1 \mathrm{H}, \mathrm{d}, J=2.0 \mathrm{~Hz})$ & 96.6 & $5.90(1 \mathrm{H}, \mathrm{d}, J=2.4 \mathrm{~Hz})$ & 96.4 \\
\hline 7 & & 167.6 & & 167.2 \\
\hline 8 & $5.88(1 \mathrm{H}, \mathrm{d}, J=2.0 \mathrm{~Hz})$ & 95.8 & $5.89(1 \mathrm{H}, \mathrm{d}, J=2.4 \mathrm{~Hz})$ & 95.5 \\
\hline $8 \mathrm{a}$ & & 164.3 & & 164.0 \\
\hline $1^{\prime}$ & & 133.5 & & 132.4 \\
\hline $2^{\prime}$ & $7.29(1 \mathrm{H}, \mathrm{d}, J=8.4 \mathrm{~Hz})$ & 128.4 & $7.44(2 \mathrm{H}, \mathrm{d}, J=8.6 \mathrm{~Hz})$ & 128.6 \\
\hline $3^{\prime}$ & $7.06(1 \mathrm{H}, \mathrm{d}, J=8.4 \mathrm{~Hz})$ & 117.1 & $7.07(2 \mathrm{H}, \mathrm{d}, J=8.6 \mathrm{~Hz})$ & 116.7 \\
\hline $4^{\prime}$ & & 158.5 & & 158.1 \\
\hline $5^{\prime}$ & $7.06(1 \mathrm{H}, \mathrm{d}, J=8.4 \mathrm{~Hz})$ & 117.1 & $7.07(2 \mathrm{H}, \mathrm{d}, J=8.6 \mathrm{~Hz})$ & 116.7 \\
\hline $6^{\prime}$ & $7.29(1 \mathrm{H}, \mathrm{d}, J=8.4 \mathrm{~Hz})$ & 128.4 & $7.44(2 \mathrm{H}, \mathrm{d}, J=8.6 \mathrm{~Hz})$ & 128.6 \\
\hline $5-\mathrm{OH}$ & & & $12.13(1 \mathrm{H}, \mathrm{s})$ & \\
\hline 7-OH & & & $10.82(1 \mathrm{H}, \mathrm{s})$ & \\
\hline \multicolumn{5}{|l|}{ glucosyl } \\
\hline $1^{\prime \prime}$ & $4.91(1 \mathrm{H}, \mathrm{d}, J=7.6 \mathrm{~Hz})$ & 101.5 & $4.89(1 \mathrm{H}, \mathrm{d}, J=7.6 \mathrm{~Hz})$ & 100.8 \\
\hline $2^{\prime \prime}$ & $3.49-3.54(1 \mathrm{H}, \mathrm{m})$ & 74.3 & $3.13-3.49(1 \mathrm{H}, \mathrm{m})$ & 73.7 \\
\hline $3 "$ & $3.49-3.54(1 \mathrm{H}, \mathrm{m})$ & 77.5 & $3.13-3.49(1 \mathrm{H}, \mathrm{m})$ & 77.6 \\
\hline $4^{\prime \prime}$ & $3.42(1 \mathrm{H}, \mathrm{m})$ & 71.5 & $3.13-3.49(1 \mathrm{H}, \mathrm{m})$ & 70.2 \\
\hline $5^{\prime \prime}$ & $3.78(1 \mathrm{H}, \mathrm{m})$ & 75.1 & $3.13-3.49(1 \mathrm{H}, \mathrm{m})$ & 77.1 \\
\hline \multirow{2}{*}{$6^{\prime \prime}$} & $4.38(1 \mathrm{H}, \mathrm{dd}, J=12.0,8.4 \mathrm{~Hz})$ & \multirow{2}{*}{64.4} & $3.13-3.49(1 \mathrm{H}, \mathrm{m})$ & \multirow{2}{*}{61.2} \\
\hline & $4.61(1 \mathrm{H}, \mathrm{dd}, J=12.0,2.0 \mathrm{~Hz})$ & & $3.70(1 \mathrm{H}, \mathrm{dd}, J=10.6,4.0 \mathrm{~Hz})$ & \\
\hline \multicolumn{5}{|l|}{ galloyl } \\
\hline $1^{\prime \prime \prime}$ & & 120.8 & & \\
\hline $2^{\prime \prime \prime}$ & $7.10(1 \mathrm{H}, \mathrm{s})$ & 109.8 & & \\
\hline $3^{\prime \prime \prime}$ & & 146.0 & & \\
\hline $4^{\prime \prime \prime}$ & & 139.4 & & \\
\hline $5^{\prime \prime \prime}$ & & 146.0 & & \\
\hline $6^{\prime \prime \prime}$ & $7.10(1 \mathrm{H}, \mathrm{s})$ & 109.8 & & \\
\hline $7^{\prime \prime \prime}(\mathrm{C}=\mathrm{O})$ & & 167.9 & & \\
\hline
\end{tabular}

${ }^{\text {a }}$ The $\delta_{\mathrm{H}}$ and $\delta_{\mathrm{C}}$ values were recorded using solvent signals $\left(\mathrm{CD}_{3} \mathrm{OD}: \delta_{\mathrm{H}} 3.31 / \delta_{\mathrm{C}} 49.0\right.$ for 1; DMSO- $d_{6}: \delta_{\mathrm{H}}$ $2.50 / \delta_{\mathrm{C}} 39.5$ for 3 ) as references. Signal assignments were based on the results of ${ }^{1} \mathrm{H}-{ }^{1} \mathrm{H}$ COSY, HMQC and HMBC experiments.

The absolute $2 S$ structure of narigenin was confirmed by the positive Cotton effect at $326.5 \mathrm{~nm}$ in the CD spectrum [6] (Figure 3). Analogous structures of $\mathbf{1}$ had been reported before [5], but the 6 "-galloyl-glucopyranosyl moiety was connected to C-7 of the naringenin aglycone. 
Figure 3. The CD spectrum and the absolute structure of 1. (A): The absolute structure of 1; (B): The conformation of 1; (C): CD spectrum of 1 in $\mathrm{MeOH}(1 \mathrm{mg} / \mathrm{mL})$.

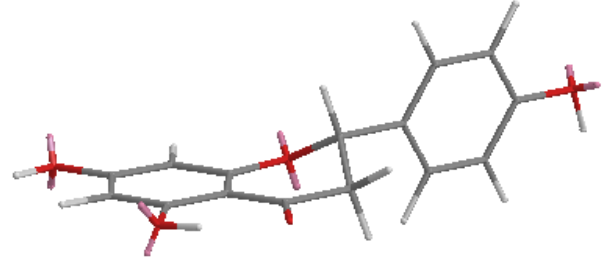

(A)

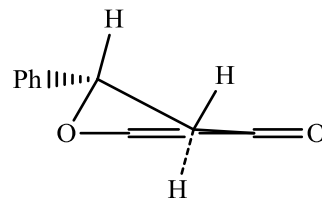

(B)

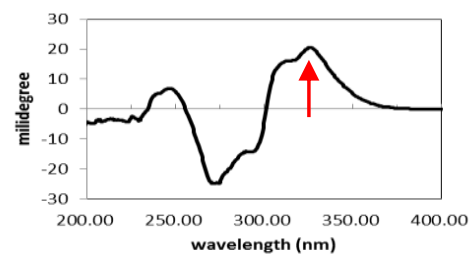

(C)

Compound 10 was obtained as a yellow crystalline powder, m.p. $196-198{ }^{\circ} \mathrm{C}(\mathrm{MeOH}),[\alpha]_{\mathrm{D}}^{24}$ $-332.7^{\circ}$ (c 0.5, MeOH), also showing a dark blue coloration with $\mathrm{FeCl}_{3}$ reagent on silica gel TLC. The ${ }^{1} \mathrm{H}-\mathrm{NMR}$ and ${ }^{13} \mathrm{C}-\mathrm{NMR}$ data of compound $\mathbf{1 0}$ were consistent with the data reported for dehydrodicatechin A [7], with an as yet undetermined absolute structure (Table 2).

Table 2. $400 \mathrm{MHz}{ }^{1} \mathrm{H}-\mathrm{NMR}$ and $100 \mathrm{MHz}{ }^{13} \mathrm{C}-\mathrm{NMR}$ data of $\mathbf{1 0}$ in $\mathrm{CD}_{3} \mathrm{OD}^{\mathrm{a}}$.

\begin{tabular}{|c|c|c|c|c|c|}
\hline Position & $\boldsymbol{\delta}_{\mathbf{H}}$ & ${ }^{1} \mathrm{H}-{ }^{1} \mathrm{H}$ COSY & $\boldsymbol{\delta}_{C}$ & HMBC $(\mathbf{H} \rightarrow \mathbf{C})$ & NOESY \\
\hline $2(\mathrm{u})$ & $3.96(1 \mathrm{H}, \mathrm{m})$ & & 78.1 & $\mathrm{C}-3(\mathrm{u}), 4(\mathrm{u}), 6^{\prime}(\mathrm{u})$ & $4(\mathrm{u})-\mathrm{Hb}$ \\
\hline $3(\mathrm{u})$ & $3.96(1 \mathrm{H}, \mathrm{m})$ & $4(u)-H$ & 65.5 & $\mathrm{C}-2(\mathrm{u}), 4(\mathrm{u}), 1^{\prime}(\mathrm{u})$ & 4(u)-Ha, 2'(u)-Ha \\
\hline \multirow{2}{*}{$4(\mathrm{u})$} & Нa:2.52 (1H, dd, $J=9.0,14.4 \mathrm{~Hz})$ & $3(\mathrm{u})-\mathrm{H}$ & \multirow{2}{*}{27.0} & \multirow{2}{*}{$\mathrm{C}-2(\mathrm{u}), 3(\mathrm{u}), 4 \mathrm{a}(\mathrm{u}), 5(\mathrm{u})$} & $3(\mathrm{u}), 4(\mathrm{u})-\mathrm{Hb}$ \\
\hline & $\mathrm{Hb}: 2.92(1 \mathrm{H}, \mathrm{dd}, J=5.8,14.4 \mathrm{~Hz})$ & $3(u)-H$ & & & 2(u), 4(u)-Ha \\
\hline $4 a(u)$ & & & 99.1 & & \\
\hline $5(\mathrm{u})$ & & & $155.0^{\mathrm{c}}$ & & \\
\hline $6(\mathrm{u})$ & \multirow[t]{2}{*}{$5.52(1 \mathrm{H}, \mathrm{d}, J=2.6 \mathrm{~Hz})^{\mathrm{b}}$} & \multirow[t]{2}{*}{$8(\mathrm{u})$} & $94.4^{\mathrm{d}}$ & \multirow[t]{2}{*}{$\mathrm{C}-4 \mathrm{a}(\mathrm{u}), 5(\mathrm{u}), 7(\mathrm{u}), 8(\mathrm{u})$} & \\
\hline $7(\mathrm{u})$ & & & $156.4^{\mathrm{c}}$ & & \\
\hline $8(\mathrm{u})$ & \multirow[t]{3}{*}{$5.89(1 \mathrm{H}, \mathrm{d}, J=2.6 \mathrm{~Hz})^{\mathrm{b}}$} & \multirow[t]{3}{*}{$6(\mathrm{u})$} & $95.7^{\mathrm{d}}$ & \multirow[t]{3}{*}{$\mathrm{C}-4 \mathrm{a}(\mathrm{u}), 6(\mathrm{u}), 7(\mathrm{u}), 8 \mathrm{a}(\mathrm{u})$} & \\
\hline $8 \mathrm{a}(\mathrm{u})$ & & & $156.7^{\mathrm{c}}$ & & \\
\hline $1^{\prime}(\mathrm{u})$ & & & 88.5 & & \\
\hline \multirow{2}{*}{$2^{\prime}(\mathrm{u})$} & Нa:2.67 (1H, d, $J=11.6 \mathrm{~Hz})$ & & \multirow{2}{*}{44.3} & \multirow{2}{*}{$\mathrm{C}-2(\mathrm{u}), 1^{\prime}(\mathrm{u}), 3^{\prime}(\mathrm{u}), 6^{\prime}(\mathrm{u})$} & $3(\mathrm{u}), 2^{\prime}(\mathrm{u})-\mathrm{Hb}$ \\
\hline & \multicolumn{2}{|l|}{$\mathrm{Hb}: 2.48(1 \mathrm{H}, \mathrm{d}, J=11.6 \mathrm{~Hz})$} & & & $2^{\prime}(\mathrm{u})-\mathrm{Ha}$ \\
\hline $3^{\prime}(\mathrm{u})$ & & & 94.0 & & \\
\hline $4^{\prime}(\mathrm{u})$ & & & 192.8 & & \\
\hline $5^{\prime}(\mathrm{u})$ & \multirow[t]{2}{*}{$6.41(1 \mathrm{H}, \mathrm{s})$} & & 111.5 & \multirow[t]{2}{*}{$\mathrm{C}-2^{\prime}(\mathrm{u}), 1^{\prime}(\mathrm{u}), 3^{\prime}(\mathrm{u}), 6^{\prime}(\mathrm{u})$} & \\
\hline $6^{\prime}(\mathrm{u})$ & & & 162.8 & & \\
\hline $2(t)$ & $4.92(1 \mathrm{H}, \mathrm{d}, J=7.5 \mathrm{~Hz})$ & $3(\mathrm{t})-\mathrm{H}$ & 82.1 & $\mathrm{C}-3(\mathrm{t}), 4(\mathrm{t}), 1^{\prime}(\mathrm{t}), 2^{\prime}(\mathrm{t}), 6^{\prime}(\mathrm{t}), 8 \mathrm{a}(\mathrm{t})$ & $4(\mathrm{t})-\mathrm{Ha}$ \\
\hline $3(t)$ & $4.11(1 \mathrm{H}, \mathrm{td}, J=7.5,5.2 \mathrm{~Hz})$ & $2(\mathrm{t})-\mathrm{H}, 4(\mathrm{t})-\mathrm{H}$ & 66.5 & $\mathrm{C}-4 \mathrm{a}(\mathrm{t})$ & $4(\mathrm{t})-\mathrm{Hb}$ \\
\hline \multirow{2}{*}{$4(t)$} & Ha:2.59 $(1 \mathrm{H}, \mathrm{dd}, J=7.5,16.4 \mathrm{~Hz})$ & $3(\mathrm{t})-\mathrm{H}$ & \multirow{2}{*}{26.5} & \multirow{2}{*}{$\mathrm{C}-2(\mathrm{t}), 3(\mathrm{t}), 4 \mathrm{a}(\mathrm{t}), 5(\mathrm{t}), 8 \mathrm{a}(\mathrm{t})$} & $2(t), 4(t)-H b$ \\
\hline & \multirow[t]{3}{*}{$\mathrm{Hb}: 2.85(1 \mathrm{H}, \mathrm{dd}, J=5.2,16.4 \mathrm{~Hz})$} & $3(\mathrm{t})-\mathrm{H}$ & & & $3(\mathrm{t}), 4(\mathrm{t})-\mathrm{Ha}$ \\
\hline $4 a(t)$ & & & 102.6 & & \\
\hline $5(\mathrm{t})$ & & & 164.9 & & \\
\hline $6(t)$ & \multirow[t]{4}{*}{$6.11(1 \mathrm{H}, \mathrm{s})$} & & 89.6 & \multirow[t]{4}{*}{$\mathrm{C}-5(\mathrm{t}), 8(\mathrm{t})$} & \\
\hline $7(\mathrm{t})$ & & & 166.7 & & \\
\hline $8(t)$ & & & 104.3 & & \\
\hline $8 \mathrm{a}(\mathrm{t})$ & & & 153.8 & & \\
\hline
\end{tabular}


Table 2. Cont.

\begin{tabular}{llllll}
\hline Position & $\boldsymbol{\delta}_{\mathbf{H}}$ & ${ }^{1} \mathbf{H}^{-1} \mathbf{H}$ COSY & $\boldsymbol{\delta}_{\boldsymbol{C}}$ & HMBC $(\mathrm{H} \rightarrow \mathrm{C})$ & NOESY \\
\hline $1^{\prime}(\mathrm{t})$ & & & 129.9 & & \\
$2^{\prime}(\mathrm{t})$ & $6.84(1 \mathrm{H}, \mathrm{d}, J=2.2 \mathrm{~Hz})$ & $5^{\prime}(\mathrm{t})$ & $113.5^{2}$ & $\mathrm{C}-2(\mathrm{t}), 4^{\prime}(\mathrm{t}), 6^{\prime}(\mathrm{t})$ & $2(\mathrm{t}), 3(\mathrm{t})$ \\
$3^{\prime}(\mathrm{t})$ & & & $145.0^{\mathrm{e}}$ & \\
$4^{\prime}(\mathrm{t})$ & & & $145.2^{\mathrm{e}}$ & \\
$5^{\prime}(\mathrm{t})$ & $6.78(1 \mathrm{H}, \mathrm{d}, J=8.0 \mathrm{~Hz})$ & $2^{\prime}(\mathrm{t}), 6^{\prime}(\mathrm{t})$ & 115.0 & $\mathrm{C}-1^{\prime}(\mathrm{t}), 3^{\prime}(\mathrm{t})$ & \\
$6^{\prime}(\mathrm{t})$ & $6.73(1 \mathrm{H}, \mathrm{dd}, J=2.2,8.0 \mathrm{~Hz})$ & $5^{\prime}(\mathrm{t})$ & 118.4 & $\mathrm{C}-2(\mathrm{t}), 2^{\prime}(\mathrm{t}), 4^{\prime}(\mathrm{t})$ & $2(\mathrm{t}), 3(\mathrm{t})$ \\
\hline
\end{tabular}

a The $\delta_{\mathrm{H}}$ and $\delta_{\mathrm{C}}$ values were recorded using solvent signals $\left(\mathrm{CD}_{3} \mathrm{OD}: \delta_{\mathrm{H}} 3.31 / \delta_{\mathrm{C}} 49.0\right)$ as references. Signal assignments were based on the results of ${ }^{1} \mathrm{H}-{ }^{1} \mathrm{H}$ COSY, HMQC and HMBC experiments signals. $\mathrm{b}-\mathrm{e}$ The signals could not be assigned exactly.

In the literature compound $\mathbf{1 0}$ was first obtained as an oxidation product of (+)-catechin [7] and in this work we also detected this compound among the products resulting from heating $(+)$-catechin, so the sterochemistry of $\mathbf{1 0}$ should be identical to that of $(+)$-catechin, except for the absolute configurations of C-1'(u) and C-3'(u) (Scheme 1). In the NOE experiment, 2'(u)-Ha showed correlation with 2(u) or 3(u)-H which were overlapped, so there were two conformations for this compound, conformation A or B (Figure 4). To determine the absolute structure of $\mathbf{1 0}$, the CD spectrum was obtained, which showed a positive Cotton effect at $336.5 \mathrm{~nm}\left(\mathrm{n}-\pi^{*}\right.$ transition). According to the helicity rule [8,9], the conformation of $\mathbf{1 0}$ should be A, and the absolute configuration of B ring should be $1^{\prime}(\mathrm{u}) S$ and $3^{\prime}(\mathrm{u}) S$, so the complete absolute structure of $\mathbf{1 0}$ was determined. Though two reports [10,11] have described the stereochemistry of $\mathbf{1 0}$, both of them ultimately referred to reference [7] which did not establish the absolute structure of $\mathbf{1 0}$, so this paper reports for the first time the whole stereochemistry of $\mathbf{1 0}$.

Scheme 1. The plausible biosynthetic pathway of compound $\mathbf{1 0}$.

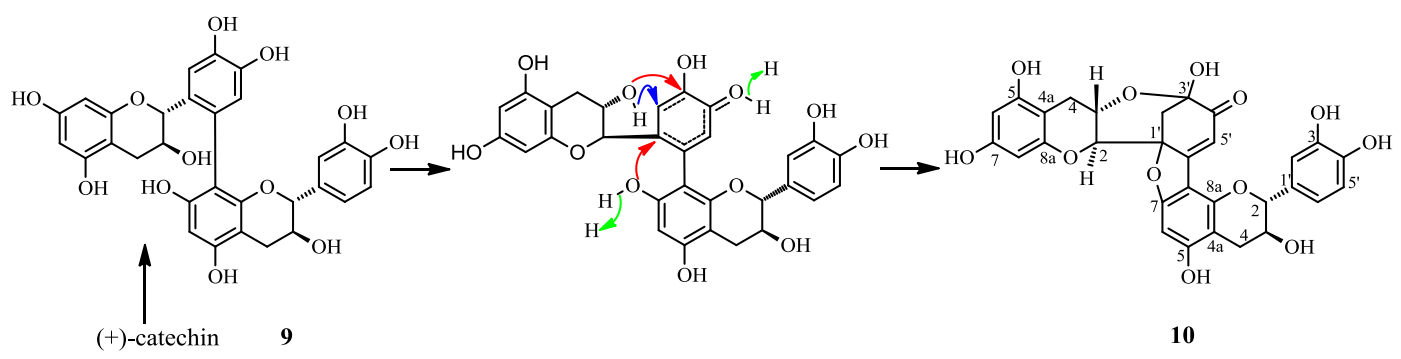

Figure 4. $(\mathbf{A}, \mathbf{B})$ the two conformations of compound 10; $(\mathbf{C})$ Standard conformation of cyclohexenone ring showing the positive $\mathrm{CE}$ and its application of the octant rule; (D) The CD spectrum of compound $\mathbf{1 0}(1 \mathrm{mg} / \mathrm{mL}, \mathrm{MeOH})$.

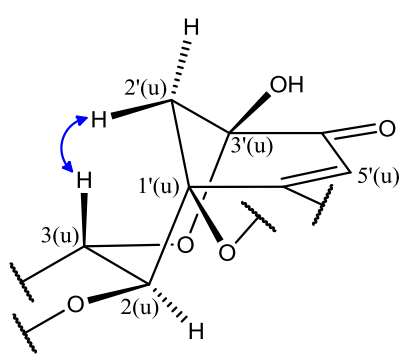

A

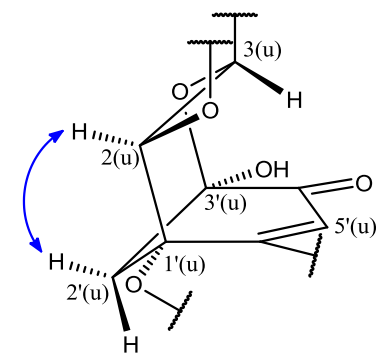

B 
Figure 4. Cont.

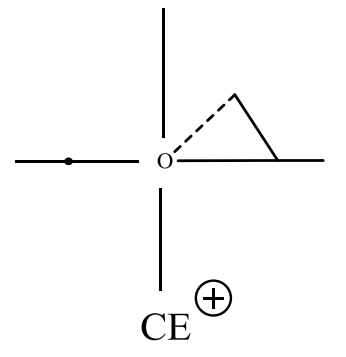

C

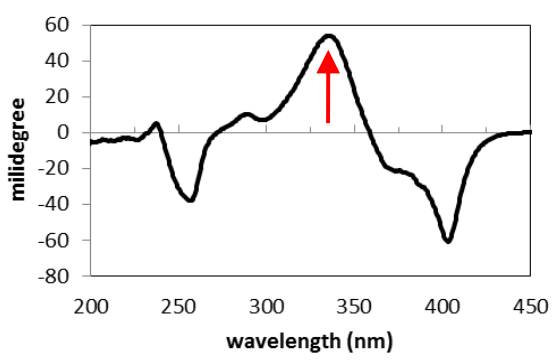

D

Compounds 2-5 were all obtained as white crystalline powders, and compound $\mathbf{6}$ was obtained as yellow needle-like crystals. On the basis of their ESI-MS, ${ }^{1} \mathrm{H}-\mathrm{NMR}$ and ${ }^{13} \mathrm{C}-\mathrm{NMR}$ spectral data, compounds 2-6 were identified as pinocembrin-7-O- $\beta$-D-glucopyranoside (2) [12], naringenin-4'-O- $\beta$ D-glucopyranoside (3) [13], dihydrokaempferol-7-O- $\beta$-D-glucopyranoside (4) [14], dihydroquercetin7-O- $\beta$-D-glucopyranoside (5) [14] and quercetin-7-O- $\beta$-D-glucopyranoside (6) [15], respectively. Compounds 7 and $\mathbf{8}$, obtained as crystalline powders, were identified as gambiriin A3 (7) [16] and gambiriin A1 (8) [17] according to the corresponding ESI-MS, ${ }^{1} \mathrm{H}-\mathrm{NMR}$ and ${ }^{13} \mathrm{C}-\mathrm{NMR}$ spectral data. The main characteristic of the structures of these two compounds is that the $\mathrm{C}$ ring of the upper unit is cleaved, which is rare in Nature. Compound 9 was identified as $(+)$-catechin $\left(6^{\prime}-8\right)(+)$-catechin [7], which was also first obtained from among the oxidation products of $(+)$-catechin in the literature [7].

\subsection{Biological Activities of $\mathbf{1}-\mathbf{1 0}$}

\subsubsection{Antitumor Activity}

The antitumor activities of $\mathbf{1 - 1 0}$ on the K562 cells were evaluated by the MTT method [9], complemented by morphological observations of the cells under a light microscope. The proliferation-inhibiting effect on K562 cells of compounds 5-8 were detected by an MTT assay, which gave inhibition rates of $26.6 \%, 65.7 \%, 40.4 \%$ and $45.6 \%$ at $100 \mu \mathrm{g} / \mathrm{mL}$, and the $\mathrm{IC}_{50}$ value of 6 is $60.7 \mu \mathrm{g} / \mathrm{mL}$. The other six compounds showed no noticeable inhibition rates on $\mathrm{K} 562$ cells, i.e., 3.4\% for $\mathbf{1}, 3.9 \%$ for $\mathbf{2},-0.5 \%$ for $\mathbf{3}, 10.4 \%$ for $\mathbf{4},-39.8 \%$ for 9 and $-16.2 \%$ for $\mathbf{1 0}$, respectively. The morphology of the cells treated with $\mathbf{1 - 4 , 9}$ and $\mathbf{1 0}$ at $100 \mu \mathrm{g} / \mathrm{mL}$ for $24 \mathrm{~h}$ showed no distinction from the control group, but inflated cell membranes and cell content leakage could be seen of the cells treated with 5-8 which showed apparent cytotoxicity on K562 cells (Figure 5). The positive control docetaxol inhibited the K562 cells with an IR\% value of $57.8 \%$ at $100 \mu \mathrm{g} / \mathrm{mL}$.

Figure 5. Photographs of K562 cells treated with 5-8 for $24 \mathrm{~h}$ at $100 \mu \mathrm{g} / \mathrm{mL}$.

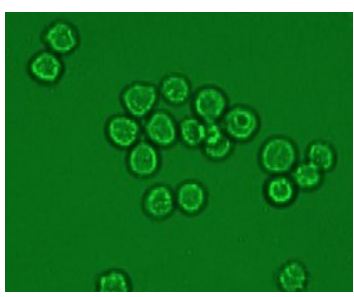

Control

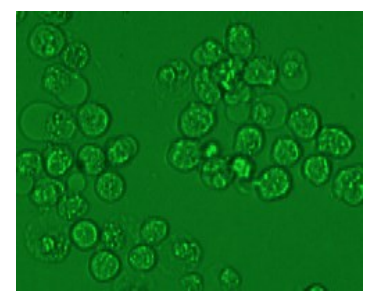

5

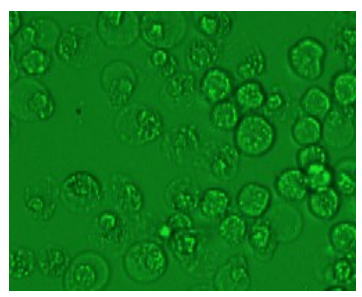

6 
Figure 5. Cont.

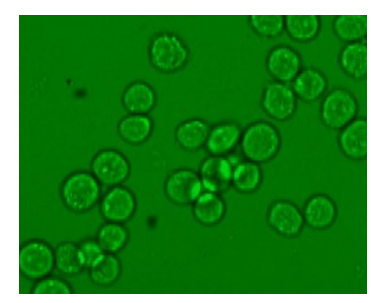

Control

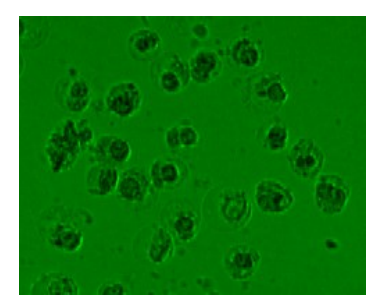

7

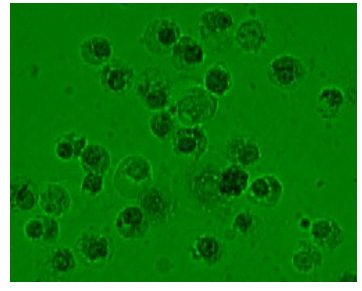

8

\subsubsection{Anti-Hypoxia Effects}

To evaluate the anti-hypoxia activities, ECV304 cells were used for $\mathbf{2}-\mathbf{5}$ and PC12 cells were used for $\mathbf{1}, \mathbf{6}-\mathbf{1 0}$ as the tested cells by the MTT method. The MTT assays showed that $\mathbf{1}-\mathbf{1 0}$ presented no cytotoxicity or inhibitory effect on ECV304 or PC12 cells, but the cell viabilities of the above two cell lines treated with $\mathbf{1}$ and $\mathbf{4 - 1 0}$ were notably increased at $50 \mu \mathrm{g} / \mathrm{mL}$ (Table 3), which suggested that $\mathbf{1}$ and 4-10 exhibited good anti-hypoxia activities.

Table 3. Anti-hypoxia effects of $\mathbf{1}$ and $\mathbf{4}-\mathbf{1 0}$ on anoxic tested cells $(50 \mu \mathrm{g} / \mathrm{mL})$.

\begin{tabular}{cccc}
\hline \multirow{2}{*}{ Samples } & \multirow{2}{*}{ Tested Cells } & \multicolumn{2}{c}{ Cell Viabilities (mean value \pm SD\%, $\mathbf{n}=\mathbf{1 0})$} \\
\cline { 2 - 4 } & & Control Group & Test Group \\
\hline $\mathbf{1}$ & PC12 & $90.0 \pm 6.1$ & $131.4 \pm 15.3 * *$ \\
$\mathbf{2}$ & ECV304 & $22.6 \pm 0.1$ & $17.1 \pm 1.2$ \\
$\mathbf{3}$ & ECV304 & $22.6 \pm 0.1$ & $27.8 \pm 1.5$ \\
$\mathbf{4}$ & ECV304 & $36.1 \pm 1.7$ & $46.4 \pm 1.0^{*}$ \\
$\mathbf{5}$ & ECV304 & $36.1 \pm 1.7$ & $51.9 \pm 0.9 * * *$ \\
$\mathbf{6}$ & PC12 & $82.8 \pm 5.3$ & $108.1 \pm 6.5 * *$ \\
$\mathbf{7}$ & PC12 & $85.9 \pm 4.0$ & $174.0 \pm 8.7 * *$ \\
$\mathbf{8}$ & PC12 & $85.9 \pm 4.0$ & $155.6 \pm 14.4 * *$ \\
$\mathbf{9}$ & PC12 & $90.0 \pm 6.1$ & $120.8 \pm 9.8 * *$ \\
$\mathbf{1 0}$ & PC12 & $90.0 \pm 6.1$ & $122.7 \pm 7.1 * *$ \\
\hline \multicolumn{2}{r}{$* P<0.05, * * P<0.01, * * * P<0.001$, compared with model group. }
\end{tabular}

\subsubsection{Anti-Bacterial Activity}

The anti-bacterial activities for 1-10 were assayed by the $8 \mathrm{~mm}$ paper disc method using Blastomyces albicans ATCC10231 and Staphylococcus aureus ATCC6538. Compounds 8 and 9 inhibited the growth of Staphylococcus aureus ATCC6538 with $15 \mathrm{~mm}$ and $14 \mathrm{~mm}$ inhibition zones at the concentration of $150 \mu \mathrm{g} /$ paper disc, respectively.

\subsection{Discussion}

Flavonoids are widely distributed in numerous plants, and have received considerable attention due to their diverse bioactivities [18,19]. Flavonoids with galloyl glucopyranosyl groups were also discovered in large numbers of plants [5,20-25]. To our knowledge, except for quercetin-4'-O-(6"-Ogalloyl- $\beta$-D-glucopyranoside) [25], the galloylglucopyranosyl groups of all these compounds was 
connected to the $\mathrm{A}$ or $\mathrm{C}$ ring of the flavonoid skeleton. Compound $\mathbf{1}$ is the second example whose galloylglucopyranosyl was connected to the B ring of the flavonoid skeleton, which is very rare in Nature. Dimeric flavans, especially catechin derivatives, are reported as being isolated both from plants $[10,11,16,17,26]$ and the oxidation products of catechin or epicatechin [7,27], and their biosynthesis and genetic regulation have also been investigated [28]. Dehydrodicatechin A (10), a dimeric flavan from $(+)$-catechin, was also isolated both from plants or among the oxidation products of $(+)$-catechin. Though the planar structure of $\mathbf{1 0}$ had been determined years ago, the exact absolute structure of this compound had not yet been established [7,10,11,27,29], so this paper, represents the first time that the absolute structure of $\mathbf{1 0}$ was established on the basis of its CD data.

\section{Experimental Section}

\subsection{General Experiment Procedures}

Melting point was measured on a Beijing Tiandiyu X-4 exact micro melting point apparatus (Tiandiyu Science and Technology Co., Ltd., Beijing, China) and the temperatures are not corrected. Optical rotations were measured on an Optical Activity Limited polAAr 3005 spectropolarimeter (Optical Activity Limited, Ramsey, UK). ESIMS was recorded on an Applied Biosystems API 3000 LC-MS spectrometer (AB SCIEX, Framingham, MA, USA) and HRESIMS was measured on an Agilent 6520 Q-TOF LC-MS spectrometer (Agilent Technologies, Santa Clara, CA, USA). IR spectra were taken on a Bruker Tensor-27 infrared spectrophotometer (Bruker, Karlsruhe, Germany). CD data were recorded on a Biologic Science MOS450 CD spectropolarimeter (Bio-Logic, Pont-de-Claix, France). 1D and 2D NMR spectra were obtained on a JEOL JNM-GX $400\left(400 \mathrm{MHz}{ }^{1} \mathrm{H}\right.$ and $100 \mathrm{MHz}$ ${ }^{13} \mathrm{C}-\mathrm{NMR}$ ) NMR spectrometer (JASCO electric Co., Ltd., Tokyo, Japan). The chemical shifts of ${ }^{1} \mathrm{H}$ and ${ }^{13} \mathrm{C}$ NMR signals were recorded in $\delta$ values using the solvent signals $\left(\mathrm{CD}_{3} \mathrm{OD}: \delta_{\mathrm{H}} 3.31 / \delta_{\mathrm{C}} 49.0\right.$; DMSO- $\left.d_{6}: \delta_{\mathrm{H}} 2.50 / \delta_{\mathrm{C}} 39.5\right)$ as references, respectively.

Precoated analytical silica gel $\mathrm{GF}_{254}$ plates $(10 \mathrm{~cm} \times 20 \mathrm{~cm}, 0.25 \mathrm{~mm}$ thickness, Yantai Chemical Industrial Institute, Yantai, China) and polyamide thin layers $(10 \mathrm{~cm} \times 20 \mathrm{~cm}$, Taizhou Luqiao Sijia Biochemical Plastic Factory, Taizhou, China) were used in TLC and spots were detected under sunlight and UV light (254 and $365 \mathrm{~nm}$ ) or by using Vaughan's reagent (24 g of ammonium molybdate tetrahydrate $\left.\left(\mathrm{NH}_{4}\right)_{6} \mathrm{Mo}_{7} \mathrm{O}_{24} \cdot 4 \mathrm{H}_{2} \mathrm{O}\right)$ and $1 \mathrm{~g}$ of ceric sulfate $\mathrm{Ce}\left(\mathrm{SO}_{4}\right)_{2}$ dissolved in $500 \mathrm{~mL}$ of $10 \%$ $\mathrm{H}_{2} \mathrm{SO}_{4}$ ) or $5 \% \mathrm{FeCl}_{3}$ reagent $\left(5 \mathrm{~g}\right.$ of $\mathrm{FeCl}_{3}$ dissolved in $100 \mathrm{~mL}$ of $95 \%$ aqueous EtOH). Silica gel $\mathrm{H}$ (100-200 mesh, Yantai Chemical Industrial Institute), YMC*GEL ${ }^{\circledR}$ ODS-A-HG (12 nm S-50 $\mu \mathrm{m}$, YMC Co., Ltd., Kyoto, Japan), Sephadex ${ }^{\mathrm{TM}}$ LH-20 (GE Healthcare, Uppsala, Sweden), and polyamide (100-200 mesh, Taizhou Luqiao Sijia Biochemical Plastic Factory) were used for column chromatography.

Human chronic myelogenous leukemia K562 cell line was provided by Prof. Dr. Song Li (Beijing Institute of Pharmacology and Toxicology, Beijing, China). Fetal bovine serum was purchased from Tianjin Hao Yang Biological Manufacture Co., Ltd. (Tianjin, China). The RPMI-1640 medium (lot No. 0803238) was purchased from Gibco (Grant Island, NY, USA) and MTT (lot No. 0793) from Amresco (Solon, OH, USA). Streptomycin (lot No. 071104) and penicillin (lot No. X0803302) were purchased from North China Pharmaceutical Group Corporation, Beijing, China. Docetaxol (DOC, lot No.20080215) was purchased from Beijing Chimivo Technology Co., Ltd. (Beijing, China). 


\subsection{Plant Material}

The stem bark of $C$. axillaries was collected in the Mengla region of Yunnan, China. The plant was identified by Professor Sun Qi-shi and a voucher specimen (No. 050901) was deposited at the Beijing Institute of Pharmacology and Toxicology.

\subsection{Extraction and Isolation}

The stem barks of $C$. axillaries $(3.2 \mathrm{~kg})$ was exhaustively extracted with $95 \%$ ethanol $(25 \mathrm{~L}$, $4 \times 7 \mathrm{~d})$ and $60 \%$ ethanol ( $25 \mathrm{~L}, 3 \times 7 \mathrm{~d})$ in turn to give $750 \mathrm{~g}$ and $90 \mathrm{~g}$ extracts, respectively. The $95 \%$ ethanol extract was further extracted from water with different organic solvents $(3 \mathrm{~L})$ to give $\mathrm{CHCl}_{3}$ extract (60 g), EtOAc extract (310 g) and $n$-BuOH extract (300 g).

The $\mathrm{CHCl}_{3}$ extract was subjected to silica gel column chromatography (bed: $7.5 \times 18.5 \mathrm{~cm}$ ) eluted with petroleum (P)-acetone (A)-methanol (M) solvent system, and the methanol eluate (12 g) was then further subjected to silica gel column chromatography and Sephadex LH-20 column chromatography to obtain 2 (300 $\mathrm{mg})$ and $\mathbf{3}(180 \mathrm{mg})$.

The EtOAc extract (100 g) was subjected to polyamide column chromatography (bed: $7.0 \times 50.0 \mathrm{~cm}$ ) eluted with EtOAc-MeOH (Et:M 1:0-0:1) to obtain four fractions, E-1 (4 g, EtOAc eluate), E-2 (35 g, Et:M 9:1 eluate), E-3 (25 g, Et:M 1:1 eluate) and E-4 (15 g, MeOH eluate). E-3 was further subjected to polyamide chromatography (bed: $3.5 \times 50.0 \mathrm{~cm}$ ) eluted with $\mathrm{CHCl}_{3}(\mathrm{C})-\mathrm{CH}_{3} \mathrm{OH}(\mathrm{M})(4: 1)$, the main fraction containing 1 was recrystallized in 30\% methanol/water solution to get 1 (517 mg). E-4 (15 g, $\mathrm{MeOH}$ eluate) was subjected to polyamide chromatography (bed: $3.8 \times 50.0 \mathrm{~cm}$ ) using a $\mathrm{CHCl}_{3}-\mathrm{CH}_{3} \mathrm{OH}$ gradient as eluting solvent, to give two fractions, E-41 and E-42. E-42 (12.0 g, MeOH eluate) was further separated by Sephadex LH-20 and polyamide column chromatography to obtain 7 (102 mg) and 8 (113 $\mathrm{mg})$.

The $n-\mathrm{BuOH}$ extract was subjected to macroporous resin AB-8 column chromatography (bed: $8.5 \times 48.0 \mathrm{~cm})$ to get a water eluate $(38 \mathrm{~g})$. The water eluate was subjected to polyamide column chromatography (bed: $7.5 \times 18.5 \mathrm{~cm}$ ) eluted with a water $(\mathrm{W})$-acetone $(\mathrm{A})$ gradient to give eight fractions, B-1 (10 g, water eluate), B-2 (2.0 g, water eluate), B-3 (1.5 g, W:A 9:1 eluate), B-4 (1.7 g, W:A 9:1 eluate), B-5 ( 2.0 g, W:A 9:1), B-6 ( 5 g, W:A 7:3 eluate), B-7 (5 g, W:A 5:5 eluate), B-8 ( 5 g, W:A 2:8 eluate). B-2 was separated by Sephadex LH-20 column chromatography (bed: $2.8 \times 27.0 \mathrm{~cm}$ ) with stepwise water-methanol (W-M) elution to obtain three fractions, B-21-B-23. Fraction B-22 (1.4 g, W:M 7:3 eluate) was further subjected to Sephadex LH-20 column chromatography (bed: $2.8 \times 60.0 \mathrm{~cm}$ ) eluted with 10\% methanol to get 4 (35 mg) and 5 (520 mg). B-23 (200 mg, methanol eluate) was also separated by Sephadex LH-20 column chromatography (bed: $2.8 \times 60.0 \mathrm{~cm}$ ) eluted with $80 \%$ methanol to obtain 6 (26 mg).

The $60 \%$ ethanol extract was subjected to polyamide column chromatography (bed: $8.5 \times 22.0 \mathrm{~cm}$ ), eluted with gradient water (W)-ethanol (E)-acetone (A) to give five fractions, 60-1 (10 g, water eluate), 60-2 (17 g, water eluate), 60-3 (2 g, W:E 3:1 eluate), 60-4 (15 g, ethanol eluate) and 60-5 (20 g, acetone eluate). Fraction 60-4 was further subjected to polyamide column chromatography (bed: $4.5 \times 50.0 \mathrm{~cm})$ eluted with an EtOAc $(\mathrm{Et})-\mathrm{MeOH}(\mathrm{M})$ gradient to give seven fractions, 60-41-60-47. 60-46 (0.7 g, Et:M 15:1 eluate) was separated by Sephadex LH-20 column chromatography (bed: 
$1.5 \times 70.0 \mathrm{~cm})$ eluted with chloroform-methanol $(1: 1)$ to obtain $9(37 \mathrm{mg}) .60-47(4.5 \mathrm{~g}$, methanol eluate) was applied to polyamide and Sephadex LH-20 column chromatography to obtain 10 (105 mg).

\subsection{Physicochemical Properties and Spectra Data}

Narigenin-4'-O-(6"-O-galloyl- $\beta$-D-glucopyranoside (1). White crystalline powder, m.p. $160-162{ }^{\circ} \mathrm{C}$ $(\mathrm{MeOH}),[\alpha]_{\mathrm{D}}^{25}-18.9^{\circ}$ (c 1.0, $\mathrm{MeOH}$ ), showing a dark blue coloration with ferric chloride reagent. Positive ion ESI-MS m/z: $587[\mathrm{M}+\mathrm{H}]^{+}, 609[\mathrm{M}+\mathrm{Na}]^{+}, 625[\mathrm{M}+\mathrm{K}]^{+}$. Positive ion HR-ESI-MS $m / z$ : $587.14907[\mathrm{M}+\mathrm{H}]^{+}, 609.12290[\mathrm{M}+\mathrm{Na}]^{+}, 625.09327[\mathrm{M}+\mathrm{K}]^{+} . \mathrm{UV}(\mathrm{MeOH}) \lambda_{\max }(\log \varepsilon): 216 \mathrm{~nm}$ (4.41), $286 \mathrm{~nm}$ (4.03). IR (KBr) $v_{\max }$ : 3293, 2947, 2882, 1685, 1637, 1607, 1517, 1460, 1343, 1316, 1230, 1188, 1161, 1065, 1038 864, 744, $723 \mathrm{~cm}^{-1}$. CD $\lambda_{\max } \mathrm{nm}(\mathrm{mdeg})$ in MeOH at $1.0 \mathrm{mg} / \mathrm{mL}: 234.0$ (0), 244 (6.4100), 255.5 (0), 272.5 (-25.0052), 301.5 (0), 326.5 (20.5810), 383.0 (0). ${ }^{1} \mathrm{H}-\mathrm{NMR}$ and ${ }^{13} \mathrm{C}-\mathrm{NMR}$ data see Table 1.

Naringenin-4'-O- $\beta$-D-glucopyranoside (3). White crystaline powder, m.p. $224-226{ }^{\circ} \mathrm{C}(\mathrm{MeOH}),[\alpha]_{\mathrm{D}}^{25}$ $-49.5^{\circ}$ (c $0.2, \mathrm{Me}_{2} \mathrm{CO}$ ), showing a brown with ferric chloride reagent. Positive ion ESI-MS $m / z$ : 435 $[\mathrm{M}+\mathrm{H}]^{+}, 457[\mathrm{M}+\mathrm{Na}]^{+}, 473[\mathrm{M}+\mathrm{K}]^{+} .{ }^{1} \mathrm{H}-\mathrm{NMR}$ and ${ }^{13} \mathrm{C}-\mathrm{NMR}$ data see Table 1.

Dehydrodicatechin A (10). Yellow crystalline powder, m.p. $196-198^{\circ} \mathrm{C}(\mathrm{MeOH}),[\alpha]_{\mathrm{D}}^{25}-332.7^{\circ}(\mathrm{c} 0.5$, $\mathrm{MeOH})$, showing a dark blue coloration with ferric chloride reagent. Positive ion ESI-MS $\mathrm{m} / \mathrm{z}$ : $577[\mathrm{M}+\mathrm{H}]^{+}, 599[\mathrm{M}+\mathrm{Na}]^{+}$; Negative ion ESI-MS m/z: $575[\mathrm{M}-\mathrm{H}]^{-} . \mathrm{CD} \lambda_{\max } \mathrm{nm}(\mathrm{mdeg})$ in $\mathrm{MeOH}$ at $1.0 \mathrm{mg} / \mathrm{mL}: 190$ (-0.3533), 232.5 (0), 237.5 (5.1513), 240 (0), 256.5 (-38.1595), 272.0 (0), 336.5 (53.8359), $358.5(0), 403.0$ (-60.7813), $456.0(0) .{ }^{1} \mathrm{H}-\mathrm{NMR}$ and ${ }^{13} \mathrm{C}-\mathrm{NMR}$ data see Table 2.

\subsection{Bioassays}

\subsubsection{Cell Line and Cell Culture}

Human myeloid leukemia K562, human umbilical vein endothelial cell ECV304, and rat pheochromocytoma PC12 cell lines were used for bioassay. The K562, ECV304 and PC12 cells were routinely maintained in RPMI-1640 (for K562 and ECV 304 cells) or DMEM (for PC12 cells) medium containing $100 \mu \mathrm{g} / \mathrm{mL}$ penicillin and $100 \mu \mathrm{g} / \mathrm{mL}$ streptomycin supplemented with $10 \%$ FBS under a humidified atmosphere of $5 \% \mathrm{CO}_{2}$ and $95 \%$ air.

\subsubsection{Cell Proliferation Assay}

Compounds 1-10 and DOC were dissolved in $\mathrm{MeOH}$ to prepare a $10.0 \mathrm{mg} / \mathrm{mL}$ solution, and serial dilutions were made for compounds 1-10. These solutions were subjected to the MTT assay. DOC was used as positive control and $\mathrm{MeOH}$ was used as blank control. The assay was run in triplicate on human cancer K562 cell lines by the method that we have previously reported [9]. 


\subsubsection{Anti-Hypoxia Assay}

Compounds 1-10 were dissolved in the DMEM or RPMI 1640 medium to prepare a solution at $50.0 \mu \mathrm{g} / \mathrm{mL}$. The anti-hypoxia activities of $\mathbf{2}-\mathbf{5}$ were assayed using ECV304 cells, but the anti-hypoxia activities of $\mathbf{1}$ and $\mathbf{6}-\mathbf{1 0}$ were assayed on PC12 cells.

MTT assay on ECV 304 cells: Exponentially growing ECV 304 cells were suspended in fresh RPMI 1640 medium at the density of $1 \times 10^{5}$ cells $/ \mathrm{mL}$ and then seeded into 96 -well plates at $150 \mu \mathrm{L} /$ well. The cells were incubated at $37^{\circ} \mathrm{C}$ for $48 \mathrm{~h}$, then discarded the medium and were assigned into normoxic control group, hypoxia control group and hypoxia administration group. Each well of the normoxic control group and hypoxia control group was added $150 \mu \mathrm{L}$ fresh RPMI 1640 medium, and the hypoxia administration group was $150 \mu \mathrm{L}$ sample solution. The hypoxia control group and hypoxia administration group were cultured in the atmosphere of $5 \% \mathrm{CO}_{2}$ and $95 \% \mathrm{~N}_{2}$ for $24 \mathrm{~h}$, while the normal control group was normally cultured for $24 \mathrm{~h}$. Then, $15 \mu \mathrm{L}$ MTT solution $(5 \mathrm{mg} / \mathrm{mL}$ in PBS) was added to each well and incubated at $37^{\circ} \mathrm{C}$ for $4 \mathrm{~h}$. Then, the MTT solution were discarded, and $150 \mu \mathrm{L}$ DMSO were added in each well; after the purple material were fully dissolved, the optical density (OD) of each well was determined on a Versa max plate reader at $490 \mathrm{~nm}$. The cell viabilities were calculated using mean values from cell viabilities $(\%)=\mathrm{OD}$ hypoxia control or $\mathrm{OD}$ sample $/ \mathrm{OD}$ normal control $\times 100 \%$.

MTT assay on PC 12 cells: Exponentially growing PC12 cells were suspended in fresh DMEM medium at the density of $1 \times 10^{5}$ cells $/ \mathrm{mL}$ and then seeded into 96 -well plates at $150 \mu \mathrm{L} / \mathrm{well}$. The cells were incubated at $37{ }^{\circ} \mathrm{C}$ for $24 \mathrm{~h}$, then discarded the medium and were assigned into normoxic control group, hypoxia control group and hypoxia administration group. Each well of the normoxic control group and hypoxia control group was added $150 \mu \mathrm{L}$ fresh DMEM medium, and the hypoxia administration group was $150 \mu \mathrm{L}$ sample solution, then all were incubated at $37^{\circ} \mathrm{C}$ for $1 \mathrm{~h}$. Each well of hypoxia control group and hypoxia administration group were added $2 \mu \mathrm{L} \mathrm{CoCl}_{2}$ solution (306.14 $\mu \mathrm{g} / \mathrm{mL}$ in water), all the three groups were incubated at $37{ }^{\circ} \mathrm{C}$. After all were normally incubated for $24 \mathrm{~h}, 15 \mu \mathrm{L}$ MTT solution $(5 \mathrm{mg} / \mathrm{mL}$ in PBS) was added to each well and incubated at $37{ }^{\circ} \mathrm{C}$ for $4 \mathrm{~h}$. Then, the MTT solution were discarded, and $150 \mu \mathrm{L}$ DMSO were added in each well; after the purple material were fully dissolved, the optical density (OD) of each well was determined on a Versa max plate reader at $490 \mathrm{~nm}$. The cell viabilities were calculated using mean values from cell viabilities $(\%)=\mathrm{OD}$ hypoxia control or $\mathrm{OD}$ sample $/ \mathrm{OD}$ normal control $\times 100 \%$.

\subsubsection{Antibacterial Effect Test}

Blastomyces albicans ATCC10231 and Staphylococcus aureus ATCC6538 were used to evaluate the antibacterial activities of compounds 1-10. Blastomyces albicans ATCC10231 was cultivated on Sabouraud's agar medium, and Staphylococcus aureus ATCC6538 was cultivated on tryptose soya agar medium. All the compounds were dissolved in methanol to prepare $10 \mathrm{mg} / \mathrm{mL}$ test sample solutions. Samples $(15 \mu \mathrm{L})$ were added to the paper discs $(8 \mathrm{~mm})$ and dried for $10 \mathrm{~min}$. Then, the discs were put on the tested plate which contained either Staphylococcus aureus or Blastomyces albicans. Tested plates were cultured at $28{ }^{\circ} \mathrm{C}$ for 2 days and then the diameter of the inhibition zone was measured. 


\section{Conclusions}

Ten flavonoids were isolated from the stem bark of $C$. axillaries. Among the obtained compounds, $\mathbf{1}$ is a new compound with a galloylglucosyl group on the B ring in the flavonoid skeleton, and compounds $\mathbf{2}$ and 4-10 were isolated from this genus for the first time. The absolute structures of $\mathbf{1}$ and 10 were established from their $\mathrm{CD}$ data, and the absolute configuration of $\mathbf{1 0}$ was determined exactly for the first time. The proliferation inhibiting activities of $\mathbf{7}$ and $\mathbf{8}$, the anti-hypoxia activities of $\mathbf{1}$ and 4-10, and the antibacterial effect of $\mathbf{8}$ and $\mathbf{9}$ on Staphylococcus aureus ATCC6538 are reported here for the first time.

\section{Supplementary Materials}

Supplementary materials can be accessed at: http://www.mdpi.com/1420-3049/19/12/21363/s1.

\section{Acknowledgments}

We thank to Song Li from Beijing Institute of Pharmacology and Toxicology for his gift of the K562 cells. The plant material was identified by Qi-Shi Sun from ShenYang Pharmaceutical University. The anti-hypoxia activities of compounds 1-10 were performed by Ming-Ming Li and Ming Fan from Beijing Institute of Basic Medical Sciences. This work was financially supported by the grants from the NSFC (81102330), NSTMP (2012ZX09301-003).

\section{Author Contributions}

Chang-Wei Li performed whole experiments for the present paper and finished the manuscript preparation. Cheng-Bin Cui conceived and designed the experiments, also contributed to the manuscript preparation.

\section{Conflicts of Interest}

The authors declare no conflict of interest.

\section{References}

1. China Pharmacopoeia Committee. Pharmacopoeia of the People's Republic of China; China Medical Science Press: Beijing, China, 2010; Volume I, p. 41.

2. Li, C.-W.; Cui, C.-B.; Cai, B.; Yao, Z.-W. The research progress of Choerospondias axillaries. Pharm. J. Chin. PLA 2008, 24, 231-234.

3. Li, C.-W.; Cui, C.-B.; Cai, B.; Han, B.; Dou, D.-Q.; Chen, Y.-J. Aromatic chemical constituents of Choerospondias axillaries and their in vitro antitumor activity. Chin. J. Med. Chem. 2005, 15, $138-147$.

4. Li, C.-W.; Cui, C.B.; Cai, B.; Han, B.; Li, M.-M.; Fan, M. Flavanoidal constituents of Choerospondias axillaries and their in vitro antitumor and anti-hypoxia activities. Chin. J. Med. Chem. 2009, 19, 48-51, 64. 
5. Barakat, H.H.; Souleman, A.M.; Hussein, S.A.M.; Ibrahiem, O.A.; Nawwar, M.A.M. Flavonoid galloyl glucosides from the pods of Acacia farnesiana. Phytochemistry 1999, 51, 139-142.

6. Slade, D.; Ferreira, D.; Marais, J.P.J. Circular dichroism, a powerful tool for the assessment of absolute configuration of flavonoids. Phytochemistry 2005, 66, 2177-2215.

7. Guyot, S.; Vercauteren, J.; Cheynier, V. Structural determination of colourless and yellow dimers resulting from $(+)$-catechin coupling catalysed by grape polyphenoloxidase. Phytochemistry 1996, $42,1279-1288$.

8. Snatzk, G. Circular dichroism and absolute conformation: Application of qualitative MO theory to chiroptical phenomen. Angew. Chem. Int. Ed. Engl. 1979, 18, 363-377.

9. Fang, S.-M.; Cui, C.-B.; Li, C.-W.; Wu, C.-J.; Zhang, Z.-J.; Li, L.; Huang, X.-J.; Ye, W.-C. Purpurogemutantin and purpurogemutantidin, new drimenyl cyclohexenone derivatives produced by a mutant obtained by diethyl sulfate mutagenesis of a marine-derived Penicillium purpurogenum G59. Mar. Drugs 2012, 10, 1266-1287.

10. Dong, Y.Q.; Shi, H.; Yang, H.S.; Peng, Y.H.; Wang, M.Y.; Li, X.B. Antioxidant phenolic compounds from the stems of Entada phaseoloides. Chem. Biodivers. 2012, 9, 68-79.

11. Shang, X.Y.; Li, S.; Wang, S.J.; Yang, Y.C.; Shi, J.G. Chemical constituents of Bauhinia aurea. J. Asian Nat. Prod. Res. 2012, 14, 966-972.

12. Hammami, S.; Ben Jannet, H.; Bergaoui, A.; Ciavatta, L.; Cimino, G.; Mighri, Z. Isolation and structure elucidation of a flavanone, a flavanone glycoside and vomifoliol from Echiochilon Fruticosum growing in Tunisia. Molecules 2004, 9, 602-608.

13. Shimoda, K.; Kubota, N.; Taniuchi, K.; Sato, D.; Nakajima, N.; Hamada, H.; Hamada, H. Biotransformation of naringin and naringenin by cultured Eucalyptus perriniana cells. Phytochemistry 2010, 71, 201-205.

14. Foo, L.Y.; Karchesy, J.J. Polyphenolic glycosides from douglas fir inner bark. Phytochemistry 1989, 28, 1237-1240.

15. Saito, N.; Cheng, J.; Lchimura, M.; Yokoi, M.; Abe, Y.; Honda, T. Flavonoids in the acyanic flowers of Pharbitis nil. Phytochemistry 1994, 35, 687-691.

16. Taniguchi, S.; Kuroda, K.; Doi, K.; Tanabe, M.; Shibata, T.; Yoshida, T.; Hatano, T. Dimeric flavans from gambir and their structural correlations with (+)-catechin. Heterocycles 2008, 76, 1171-1180.

17. Taniguchi, S.; Kuroda, K.; Doi, K.; Tanabe, M.; Shibata, T.; Yoshida, T.; Hatano, T. Revised Structures of Gambiriins A1, A2, B1, and B2, Chalcane-Flavan Dimers from Gambir (Uncaria gambir Extract). Chem. Pharm. Bull. 2007, 55, 268-272.

18. Mamta, G.; Bansal, Y.K.; Sandhu, S.S. Recent patents on flavonoids. Recent Pat. Biotechnol. 2013, 7, 179-196.

19. Ferreyra, M.L.F.; Rius, S.P.; Casati, P. Flavonoids: Biosynthesis, biologicalfunctions, and biotechnological applications. Front. Plant Sci. 2012, 3, 1-15.

20. Zhang, Y.J.; Abe, T.; Tanaka, T.; Yang, C.R.; Kouno, I. Two new acylated flavanone glycosides from the leaves and branches of Phyllanthus emblica. Chem. Pharm. Bull. 2002, 50, 841-843.

21. Liu, R.N.; Wang, W.; Ding, Y.; Xie, W.D.; Ma, C.; Du. L.J. A new flavonol glycoside and activity of compounds from the flower of Nymphaea candida. J. Asian Nat. Prod. Res. 2007, 9, 333-338. 
22. Kim, J.E.; Jung, M.J.; Jung, H.A.; Woo, J.J.; Cheigh, H.S.; Chung, H.Y.; Choi, J.S. A new kaempferol 7-O-triglucoside from the leaves of Brassica juncea L. Arch. Pharmacal. Res. 2002, 25, 621-624.

23. Nishimura, T.; Wang, L.Y.; Kusano, K.; Kitanaka, S. Flavonoids That Mimic Human Ligands from the Whole Plants of Euphorbia lunulata. Chem. Pharm. Bull. 2005, 53, 305-308.

24. Masuda, T.; Iritani, K.; Yonemori, S.; Oyama, Y.; Takeda, Y. Isolation and antioxidant activity of galloyl flavonol glycosides from the seashore plant, Pemphis acidula. Biosci. Biotechnol. Biochem. 2001, 65, 1302-1309.

25. Okamura, H.; Mimura, A.; Niwano, M.; Takahara, Y.; Yasuda, H.; Yoshida, H. Two acylated flavonol glycosides from Eucalyptus rostrata. Phytochemistry 1993, 33, 512-514.

26. Foo, L.Y.; Lu, Y.R.; Wong, H. Biphenyl-linked biflavanoids from grape pomace. Phytochemistry 1998, 47, 1137-1140.

27. Sang, S.M.; Tian, S.Y.; Wang, H.; Stark, R.E.; Rosen, R.T.; Yang, C.S.; Ho, C.T. Chemical studies of the antioxidant mechanism of tea catechins: Radical reaction products of epicatechin with peroxyl radicals. Bioorg. Med. Chem. 2003, 11, 3371-3378.

28. He, F.; Pan, Q.H.; Shi, Y.; Duan, C.Q. Biosynthesis and genetic regulation of proanthocyanidins in plants. Molecules 2008, 13, 2674-2703.

29. Yan, G.Q.; Li, S.P.; Hu, J.; Zhai, X.Y.; Ma, W.; Li, N.; Wang, K.J. Phenolic constituents from the roots of Rosa laevigata (Rosaceae). Biochem. Syst. Ecol. 2014, 52, 23-26.

Sample Availability: Samples of all the compounds are available from the authors.

(C) 2014 by the authors; licensee MDPI, Basel, Switzerland. This article is an open access article distributed under the terms and conditions of the Creative Commons Attribution license (http://creativecommons.org/licenses/by/4.0/). 